\title{
Use of extractable lipofuscin to estimate age structure of ghost shrimp populations in west coast estuaries of the USA
}

\author{
Katelyn M. Bosley ${ }^{1, *}$, Brett R. Dumbauld ${ }^{2}$ \\ ${ }^{1}$ Oregon State University, Hatfield Marine Science Center, 2111 S.E. Marine Science Drive, Newport, Oregon 97365, USA \\ ${ }^{2}$ US Department of Agriculture, Agricultural Research Service, 2030 S.E. Marine Science Drive, Newport, Oregon 97365, \\ USA
}

\begin{abstract}
Determining age in crustaceans is inherently imprecise because they molt periodically and do not retain hard structures throughout their lifespan. Morphological measurements are often used to estimate age, but variability in individual growth rate and molt frequency can result in a wide distribution of sizes in a single age class, making size a poor predictor of true age. Concentration of the autofluorescent age pigment, lipofuscin, has been shown to be directly related to actual age in many crustaceans. The present study assessed the potential of using extractable lipofuscin as a method for determining age in the ghost shrimp Neotrypaea californiensis. Following validation of the technique, lipofuscin-based aging was used to determine age structures for 3 populations of $N$. californiensis, and these were compared to age structures determined using traditional lengthbased methods. Analysis of lipofuscin revealed up to 13 age classes where the size-based analysis showed only 7. Comparison of mean size-at-age among populations in Oregon and Washington estuaries demonstrated that growth rate varied spatially, probably responding to site-specific environmental factors like food availability and population density. $N$. californiensis negatively impact oyster aquaculture in Pacific Northwest estuaries. Analysis of extractable lipofuscin proved to be a more accurate method of age determination than body-length measurements and should facilitate more indepth investigations of basic biological and ecological processes, which will benefit current efforts to develop an integrated pest management plan for N. californiensis.
\end{abstract}

KEY WORDS: Callianassidae - Neotrypaea californiensis · Lipofuscin · Willapa Bay · Age pigment · Age structure $\cdot$ Growth

\section{INTRODUCTION}

Age is an important parameter used to develop population dynamics models and estimate population parameters, such as growth rate, age-at-maturity, mortality and fecundity. Unlike fishes or molluscs, crustaceans do not have calcified structures that they retain throughout their life span. All hard parts are shed during molting, which makes obtaining accurate estimates of age problematic. Traditionally, morphometric measurements, such as carapace length or width, have been used as a surrogate for age in crus- taceans. However, variability in individual growth rate and molt frequency can cause a wide distribution of sizes in a single age class, making it difficult to distinguish cohorts based on body size (Parsons \& Fréchette 1989, Wahle et al. 1996, Belchier et al. 1998, Sheehy et al. 1998, Ju et al. 2001). Growth rates in crustaceans are influenced by a wide array of biotic (e.g. density dependant) and abiotic (e.g. environmental) factors (Newman \& Pollock 1974, Klein Breteler 1975, Ra'anan \& Cohen 1985, Hartnoll 2001). Given that growth rates among individuals or cohorts can vary, building agebased population models and empirically deriving 
population parameters from length-based estimates of age adds significant sources of error when assessing crustacean populations for management or conservation applications.

The ghost shrimp Neotrypaea californiensis Dana, 1854 (formerly Callianassa californiensis; Manning \& Felder 1991) is found in West Coast estuaries from Alaska, USA, to Baja California, Mexico. These thalassinidean shrimp inhabit vast expanses of the intertidal zone, affecting sediment stability and community composition through their burrowing activities and acting as geochemical engineers (MacGinitie 1934, Posey 1986, 1987, D'Andrea \& DeWitt 2009). They are a pest to oyster aquaculture operations in Pacific Northwest estuaries, by causing oyster mortality via sedimentation during burrowing. As a result, oyster growers operating on infested oyster grounds often experience significant economic losses (Feldman et al. 2000). Since the 1960s, oyster growers have controlled burrowing shrimp populations by applying a pesticide, carbaryl, to intertidal mudflats (WDF 1970). Increasing concern over the environmental impacts associated with using carbaryl as a form of control has led the industry to pursue integrated pest management (IPM) of burrowing shrimp on oyster grounds (DeWitt et al. 1997, Dumbauld et al. 2006). Several critical needs for implementing a successful IPM strategy have been identified, including the development of methods for conducting burrowing shrimp population censes and constructing population models (DeWitt et al. 1997).

Accurate population models require adequate understanding of the life history and reproductive biology of the organism. Previous life-history studies on Neotrypaea californiensis have examined recruitment, size-at-maturity, growth rate and mortality for populations in Oregon and Washington estuaries (Dumbauld et al. 1996, 2001), but researchers used body-length measurements as a proxy for age. Significant variation in the maximum body size of $N$. californiensis populations within and among estuaries (Bird 1982, Dumbauld et al. 1996) has been assumed to be a result of variable growth rates, but cohorts comprised of large animals are impossible to separate, making it difficult to use size as a criterion for estimating population parameters. This led us to seek alternative approaches to estimate age and conduct demographic assessments for this species.

The use of age-related fluorescent pigments, lipofuscins (LF), for aging has shown promise for ecological and population studies in crustaceans. Lipofuscins accumulate within post-mitotic (i.e. neural, muscle, cardiac, retinal pigment epithelium) tissues as a result of free-radical-induced lipid peroxidation processes (Sheldahl \& Tappel 1974, Porta 1991). Because LF is a product of metabolism and is retained in neural tissues throughout an organism's lifespan, analysis of LF content reflects the metabolic history or 'physiological age' of an individual. Several studies comparing body size and age estimated from LF content have shown LF to be highly correlated to age even when size shows considerable scatter (Sheehy et al.1994, 1998, O'Donovan \& Tully 1996, Ju et al. 1999, Bluhm \& Brey 2001, Bluhm et al. 2001a). LF-based aging techniques have been effectively used to estimate age in a number of economically and ecologically important crustaceans, including the blue crab Callinectes sapidus (Ju et al. 2002), the Antarctic amphipod Waldeckia obesa (Bluhm et al. 2001b), the edible crab Cancer pagurus (Sheehy \& Prior 2005, 2008), the European lobster Homarus gammarus (Sheehy \& Bannister 2002), the western rock lobster Panulirus cygnus (Sheehy et al. 1998) and the stomatopod Oratosquilla oratoria (Kodama et al. 2006).

The 2 techniques used in LF age determination are histological and extraction based. The most commonly applied technique involves analysis of histological sections by quantifying, through fluorescence microscopy, the number and size of lysosomal granules containing the pigment (Sheehy 1989, 1990a). Estimations using the histological method have shown great precision, often predicting ages within a few months (or years for long-lived species) of the actual chronological age of the animal (Sheehy 1990b, Wahle et al. 1996, Belchier et al. 1998, Maxwell et al. 2007). However, sample sizes tend to be small because of the time commitment involved, reducing the statistical power of the method. The second method involves extraction of hydrophobic age-pigments with organic solvents and subsequent measurement of fluorescence intensity through spectrophotometry (Ettershank et al. 1983). The extraction method has been subject to a number of different criticisms (Sheehy 1996, 2008, Harvey et al. 2008), but, with proper validation techniques, it provides an appealing alternative to the morphological method because it requires less time and allows greater sample sizes to be processed (Ju et al. 1999, Puckett et al. 2008).

Obtaining accurate estimates of age using extractable LF for any species requires identification of the age-related product in tissue extracts and calibration of the LF-based estimates of age. This can be accomplished by rearing animals in the laboratory to track changes in the concentration of the fluorescence age pigment over time (Vila et al. 2000, Ju et al. 2001, Puckett et al. 2008). Chronological age estimates are then assigned to an animal based on the concentration of LF in a tissue sample. For many species that are long-lived or difficult to culture in the laboratory, statistical separation of modes derived from LF concentration frequency histograms is used to estimate the num- 
ber of age classes in wild populations. Separation of age classes based on LF content often reveals more age classes in a population than was predicted using analysis of length-frequency data, indicating that many crustaceans live to be much older than previously thought, and estimates of age based on body length may be inaccurate because of the weak correlation of body size with true age (Sheehy et al. 1998, Bluhm et al. 2001b, Ju et al. 2002, Sheehy \& Prior 2005, Kodama et al. 2006).

The purpose of the present study was to assess the potential for using extractable LF as an biomarker in assessing the age structure of ghost shrimp populations in West Coast estuaries. A field growth experiment was conducted to validate the method and calibrate an age model. Demographic assessments were then conducted using LF as an age biomarker to estimate age structure for multiple populations among and within 2 estuaries on the West Coast. The age information determined in the demographic analysis was used to construct an LF-based age model, which predicts actual age from LF content. This is the first study to apply biochemical methods to determine age and assess population age structure for a thalassinidean shrimp species. Establishing an accurate method of age estimation makes it possible to create more robust population models describing growth, recruitment, age-at-maturity and mortality for Neotrypaea californiensis and provides a criterion for comparing populations from different geographic regions. In addition, the methods described here can be applied to other thalassinidean shrimp species to advance understanding in aging, growth and population biology for this important taxonomic group of ecosystem engineers.

\section{MATERIALS AND METHODS}

Verification of LF-based aging methods. Study sites: A growth study was conducted in Yaquina Bay, Oregon, USA, to verify the use of LF as an age biomarker for Neotrypaea californiensis and assess differences in LF accumulation and growth rate at multiple sites within the bay. Yaquina Bay $\left(44^{\circ} 37^{\prime} 08.07^{\prime \prime} \mathrm{N}\right.$, $124^{\circ} 02^{\prime} 29.68^{\prime \prime} \mathrm{W}$ ) is located on the central coast of the state of Oregon and is classified as a coastal plain estuary. The Yaquina River is the primary tributary that feeds into the bay. The bay is relatively small, encompassing $\sim 17.1 \mathrm{~km}^{2}$ at mean high water, with the Yaquina River as the primary tributary (Shirzad et al. 1988) (Fig. 1). The average tidal range of the bay is $2 \mathrm{~m}$, which exposes $8.2 \mathrm{~km}^{2}$ of tide flat at mean low water (MLLW;Percy et al. 1974, Dumbauld \& McCoy unpubl. data). Dense populations of thalassinid shrimps are found across the intertidal area of Yaquina
Bay, and population density can exceed 500 ind. $\mathrm{m}^{-2}$ in some locations (DeWitt et al. 2004).

Three sites were selected for the field growth experiment, Seawall Island (SWI), Idaho Flats High (IFH) and Idaho Flats Low (IFL; Fig. 1). Each site represents a different level of marine influence, tidal elevation and population density within the bay. Burrow counts were used as a proxy for population density at each site. SWI is located on the northern side of the first bend in the Yaquina River, closest to the estuary mouth. This site is lowest in tidal elevation $(0.13 \mathrm{~m}$ MLLW) and is only exposed during the lower low tides of the mixed semidiurnal tidal cycle. SWI is the site of a small ghost shrimp population. Shrimp density is low $\left(104 \pm 18.4\right.$ burrows $\left.\mathrm{m}^{-2}\right)$, and shrimp sampled at this location were noticeably larger than shrimp collected from other sites in the bay. IFH is located on the upper edge of the intertidal zone (1.5 m MLLW) on the northwestern side of the Idaho mud flat behind the Hatfield

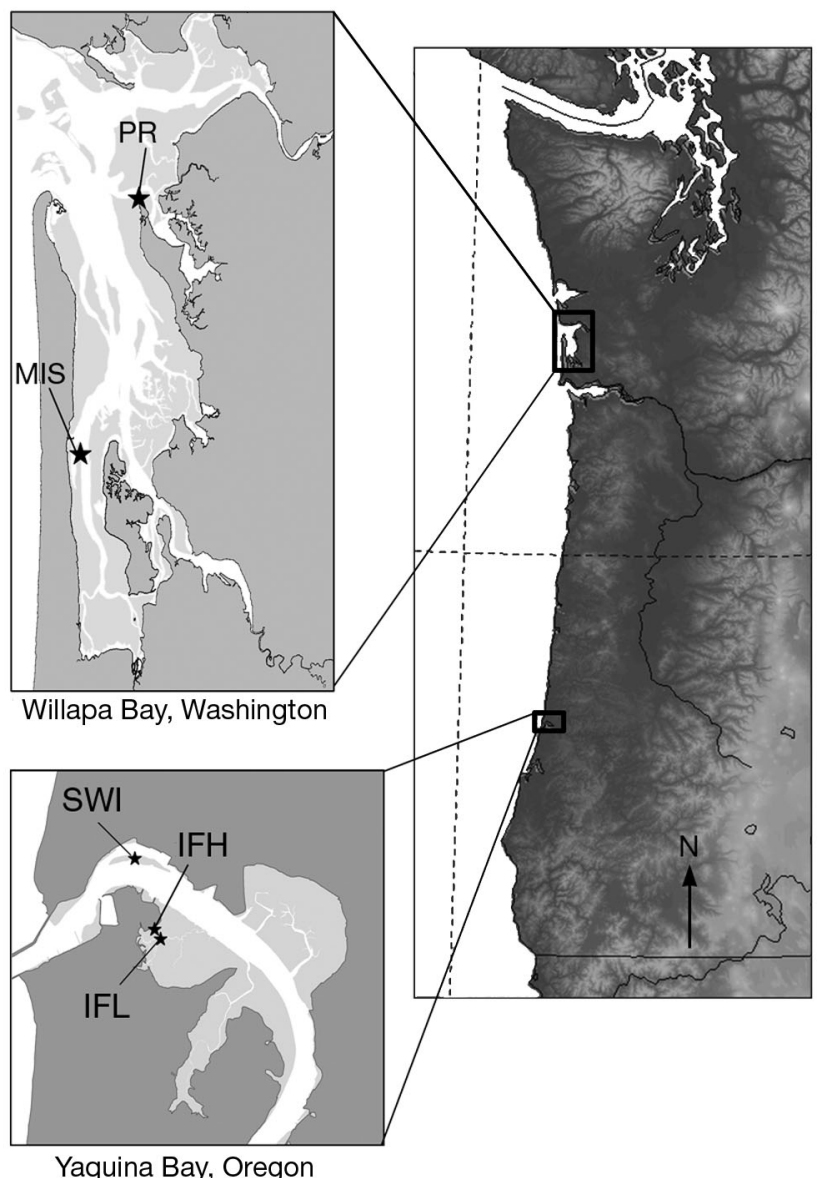

Yaquina Bay, Oregon

Fig. 1. Study sites within Willapa Bay (WB), WA, and Yaquina Bay (YB), OR, USA. Population surveys were conducted at Idaho Flats High (IFH), Middle Island Sands (MIS), and Palix River (PR). The field calibration study was conducted in Yaquina Bay. SWI: Seawall Island; IFL: Idaho Flats Low 
Marine Science Center. A large resident population of ghost shrimp inhabits this site, and population density was very high, with burrow counts averaging $537 \pm$ 33.7 burrows $\mathrm{m}^{-2}$. The third study site, IFL, is located about $70 \mathrm{~m}$ to the southeast of IFH along the lower edge of the ghost shrimp population on Idaho Flats. This site is lower in the intertidal than IFH $(1.43 \mathrm{~m}$ MLLW) and closer to the main channel. Shrimp density is lowest at IFL, with an average of $59.6 \pm 21.0$ burrows $\mathrm{m}^{-2}$.

A survey of the IFH population was conducted to determine an appropriate 'reference age class' for the growth/calibration study. This was done to select animals of similar age that were small enough to exhibit short-term growth, yet still of sufficient size to effectively remove neural tissue. Scarcity of juveniles and difficulties with culturing Neotrypaea californiensis in the laboratory did not allow for animals of known age to be used for estimating LF accumulation rate; therefore, the 'reference age class' was selected using previously described size-at-age estimates. Ten large cores $\left(0.085 \mathrm{~m}^{3}\right)$ were randomly taken from the IFH study site, where animals were most abundant. Material from cores was excavated and sieved with a $2 \mathrm{~mm}$ mesh sieve to collect all animals contained in the core and gain a representative sample of the population. Shrimp were sexed, and carapace length (CL) was measured to the nearest tenth of a millimeter. Modal progression analyses $\left(\mathrm{MPA}_{i}\right.$ see statistical analysis section below for description) of length-frequency data from both sexes were used to determine the size class that would be used in the study. Four size classes were identified in the IFH population, with a small group occurring between 5.9 and $9.1 \mathrm{~mm} \mathrm{CL}$ (Table 1). This size

Table 1. Neotrypaea californiensis. Results of modal progression analysis (MPA) of length-frequency data from the April survey in 2007. Separation indices (SI) $>2$ indicate significant separation of modes. Age classes are assumed based on Dumbauld et al. (1996). CL: carapace length; SD: standard deviation; $\mathrm{N}$ : number of measured individuals; NA: not applicable

\begin{tabular}{|lccrc|}
\hline $\begin{array}{l}\text { Assumed age } \\
\text { class (yr) }\end{array}$ & $\begin{array}{c}\text { Mean CL } \\
(\mathrm{mm})\end{array}$ & $\mathrm{SD}$ & $\mathrm{N}$ & $\mathrm{SI}$ \\
\hline Females & & & & \\
2 & 7.54 & 0.87 & 18 & $\mathrm{NA}$ \\
3 & 9.61 & 0.38 & 40 & 3.31 \\
4 & 10.53 & 0.38 & 87 & 2.42 \\
5 & 11.86 & 0.75 & 46 & 2.35 \\
Males & & & & \\
1 & 5.02 & 0.39 & 3 & $\mathrm{NA}$ \\
2 & 7.49 & 0.81 & 14 & 4.12 \\
3 & 10.97 & 1.27 & 75 & 3.35 \\
4 & 14.65 & 0.73 & 5 & 3.68 \\
\hline
\end{tabular}

group was selected as the 'reference age class', and it was assumed that these animals were $2 \mathrm{yr}$ old based on growth and size-at-age estimates described by Dumbauld et al. (1996).

A total of 350 individuals in the reference age class ranging in size from 4.8 to $8.8 \mathrm{~mm}$ CL were collected from the IFH study site. Thirty animals were saved as an initial sample to determine average LF index and CL at the start of the study (time $=0$ ). The remaining shrimp were then randomly placed in cages at each study site and allowed to grow for the duration of the study. Cages consisted of 201 buckets placed in the sediment at each site. Holes $(7.6 \mathrm{~cm})$ were drilled into the bottom and sides of each bucket, and openings were covered with $1 \mathrm{~mm}$ fine mesh screen, which prevented shrimp movement and allowed natural porewater tidal flow. At each site, 4 cages were placed and from 20 to 30 animals were randomly assigned to each cage. Mesh lids were placed on cages to keep immigration or emigration from contaminating the samples and to reduce predation on the shrimp. Cages were randomly chosen to be sampled at 2 to 3 mo intervals between July 2007 and April 2008, to monitor growth and LF accumulation rate. Temperature probes were placed 10 $\mathrm{cm}$ below the sediment surface at each site to record in situ temperature at $30 \mathrm{~min}$ intervals. Temperature data were used to qualitatively assess the effect of ambient temperature on growth and LF accumulation at each study site. All animals recovered were sexed, and carapace length was measured to the nearest millimeter. The shrimp were then analyzed for extractable LF content using the methods described below.

Extraction and quantification of LF: Procedures to extract and quantify LF were modified from the methods described by Ju et al. (1999). Brains of Neotrypaea californiensis were dissected, and LF was extracted from brain tissue using a 2:1 mixture of dichloromethane $\left(\mathrm{CH}_{2} \mathrm{CL}_{2}\right)$ and methanol $(\mathrm{MeOH})$. Each sample was sonicated at $18 \%$ for $30 \mathrm{~s}$ to release LF into the solution. Samples were then centrifuged at $800 \mathrm{~g}$ for $10 \mathrm{~min}$ to remove cellular debris. Half of the total extract $(500 \mu \mathrm{l})$ was transferred into a $1 \mathrm{ml}$ amber vial where contents were dried under $\mathrm{N}_{2}$ and re-dissolved in $250 \mu \mathrm{l} \mathrm{MeOH}$. Samples were analyzed with an Agilent 1100 scanning fluorescence detector. Fluorescence intensity of each sample was measured at the $615 \mathrm{~nm}$ emission wavelength, with excitation at $281 \mathrm{~nm}$. This excitation/emission (Ex/Em) maximum represents the major age-related fluorescence peak found in brain tissue extracts of $N$. californiensis (Cassidy 2008). Fluorescence peaks were maximized with a $15 \mu \mathrm{l}$ sample injection and a flow rate of $0.8 \mathrm{ml} \mathrm{min} \mathrm{mi}^{-1}$ using HPLC grade $\mathrm{MeOH}$ as the carrier solvent. 
LF concentration was quantified by calibrating fluorescence intensity with a standard of quinine sulfate dissolved in $0.1 \mathrm{~N} \mathrm{H}_{2} \mathrm{SO}_{4}$. Pigment concentration was then normalized to protein concentration in the extract. Total protein concentration in each sample was quantified using the bicinchoninic acid assay (Smith et al. 1985). The final measurement was expressed as a protein-normalized LF index (ng LF $\mu^{-1}$ protein) such that:

LF index $=$ [Extractable LF concentration $\left(\mathrm{ng} \mu \mathrm{g}^{-1}\right)$ calibrated versus quinine sulfate $\left.\left(\mathrm{ng} \mathrm{ml}^{-1}\right)\right] \times[$ Total protein content (extract and tissue) $\left.\left(\mu \mathrm{g} \mathrm{ml}^{-1}\right)\right]^{-1}$

This index of age was treated as a dependent variable in all regression analyses.

Statistical analysis: Average size of animals in the 'reference class' was determined with a modal progression analysis (MPA) of length data. This method employs a statistical procedure that breaks a frequency distribution into a series of Gaussian components. Initial estimations for means and standard deviations of modes identified in the length-frequency histograms were determined using Bhattacharya's method (Bhattacharya 1967), and the separation of modes was then tested using the NORMSEP routine in the FiSAT II statistical software program (Gayanilo et al. 2005). The NORMSEP routine applies the maximum-likelihood concept to separate normally distributed components of frequency distributions (Hasselblad 1966). Modes with a separation index $>2$ were considered to be significantly separated (Gulland \& Rosenberg 1992), and age classes were assigned to these modes based on existing estimates of size-at-age for the first 2 yr of growth (Dumbauld et al. 1996).

Least-squares linear regression analyses were conducted to determine if the LF index and body size increased with time. Simple linear regression models were constructed with untransformed data using body length and the LF index as dependant variables and time as the predictor variable for each site. Multiple regression models were then constructed using both time and site as predictor variables. Interactions were examined to determine if slopes and intercepts of regression models from each site were statistically different from each other. An outlier analysis was performed, and measurements that had studentized residuals with an absolute value $>4$ were removed from the data set. A total of 8 outliers were removed, representing $3.5 \%$ of the data set. These outliers may have occurred from errors in the age pigment extraction procedure or immigration of significantly older or younger animals into the buckets when mesh lids were broken. Prior to analysis, all data were tested to assure the assumptions of normality and homoscedascity were met. Regression analyses were conducted using the statistical programs R (R Development Core Team 2008) and SigmaStat 3.5.

Demographic assessment of West Coast shrimp populations. Study sites: Demographic assessments were conducted in 2 Pacific Coast estuaries, Willapa Bay, Washington, and Yaquina Bay, Oregon, USA. Willapa Bay $\left(46^{\circ} 33^{\prime} 42.13^{\prime \prime} \mathrm{N}, 123^{\circ} 58^{\prime} 05.37^{\prime \prime} \mathrm{W}\right)$ is located in southwestern Washington State, just north of the Columbia River (Fig. 1). It is classified as a coastal plain estuary, with a connection to the highly active eastern boundary of the Pacific Ocean and California Current System (Hickey 1989). The bay encompasses a total area of $260 \mathrm{~km}^{2}$ at mean high water and is relatively shallow, with $<15 \%$ being deeper than $7 \mathrm{~m}$ (Hedgepeth \& Obrebski 1981). Willapa Bay is a major site for oyster aquaculture on the West Coast, producing $\sim 10 \%$ of the commercial oysters harvested in the United States (Ruesink et al. 2006). Dense populations of Neotrypaea californiensis occur in sandy sediment throughout the bay. Ghost shrimp habitat makes up $\sim 13.5 \%$ of the total intertidal area of the bay, with most of the populations occurring near the mouth, where marine influence is highest (Dumbauld et al. 2009).

For the assessments, 3 sites were selected 2 in Willapa Bay and 1 in Yaquina Bay (see description above; Fig. 1), to have high shrimp density and amongsite differences in mean CL (Fig. 2), potentially reflecting differences in growth rate. The 2 sites in Willapa Bay represent different levels of marine influence and tidal circulation. The Palix River (PR) site is located near the mouth of the bay $(13 \mathrm{~km})$ and receives strong marine influence from coastal waters intruding into the estuary, while the second site, Middle Island Sands (MIS), is located $27 \mathrm{~km}$ from the mouth of the bay. Tidal elevation at the 2 sites was similar $(\sim 0.50 \mathrm{~m}$ MLLW), and population density differed slightly, with $132 \pm 35$ burrows $\mathrm{m}^{-2}$ at PR and $170 \pm 44.2$ burrows $^{-2}$ at MIS (mean \pm SD). Shrimp at MIS were noticeably smaller than those found at PR. The third site, Idaho Flats (IF), was selected as the Yaquina Bay sampling site (see site description of IFH above). The size of shrimp at IF tended to be small in comparison to those in Willapa Bay populations of N. californiensis selected for the present study. Average population density at IF was also highest, with $429 \pm 162$ burrows $\mathrm{m}^{-2}$. Because of the higher population density and smaller average size of shrimp at IF, it was expected that shrimp from this location would exhibit the lowest growth rate of the 3 populations surveyed.

Sample collection: Shrimp were collected by taking 10 large cores (40 $\mathrm{cm}$ diameter) to a $60 \mathrm{~cm}$ depth at each location. Material from each core was excavated, sieved ( $2 \mathrm{~mm}$ mesh) and sorted for shrimp. All animals were then sexed, and CL was measured prior to being frozen for LF analysis. A minimum sample size of 150 

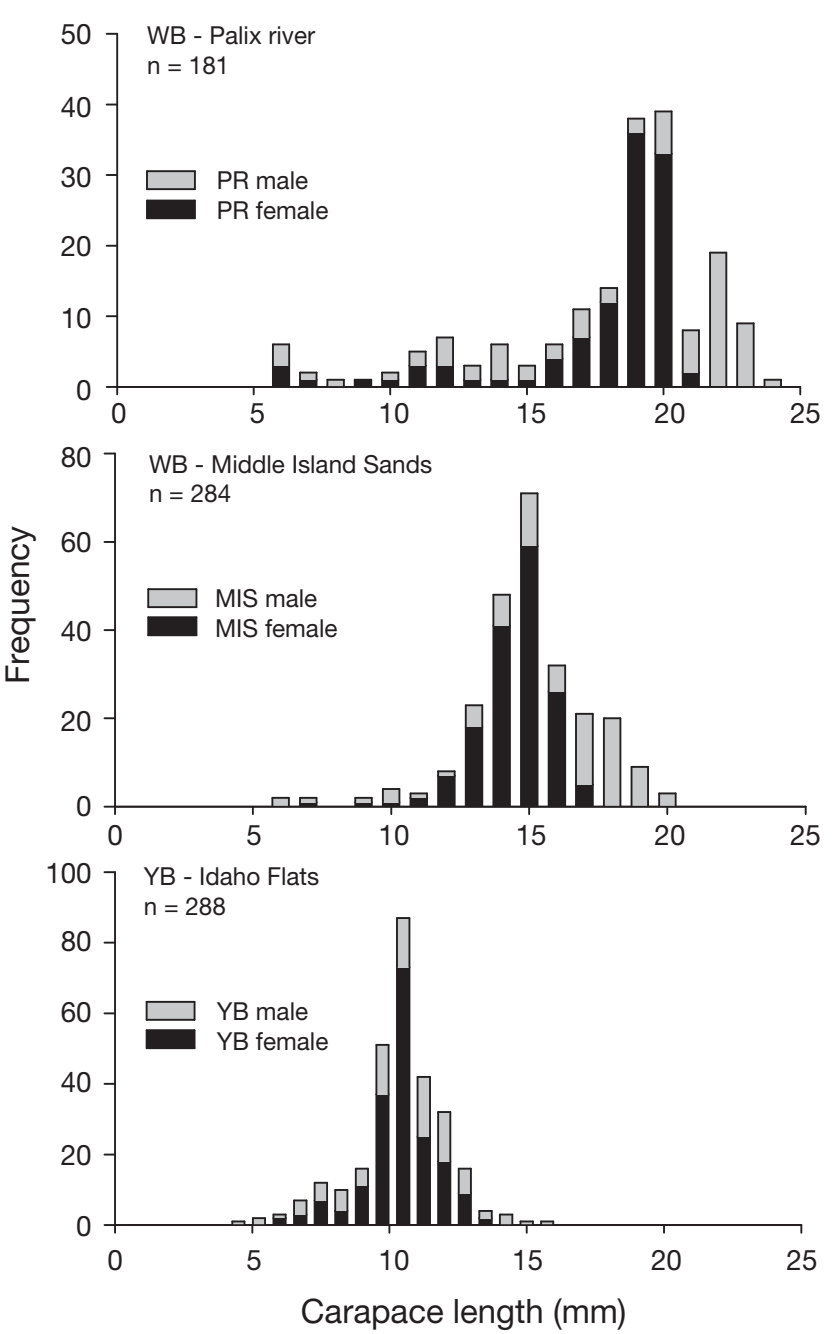

Fig. 2. Neotrypaea californiensis. Length-frequency distributions from each site surveyed for demographic assessments. Males and females differed significantly with respect to body length at each site (Kolmogorov-Smirnov test, $\mathrm{p}<0.5$ in all cases). See Fig. 1 for site abbreviations

animals was collected from each site. Preliminary analysis of molting frequency in Neotrypaea californiensis has shown that the majority of growth occurs during the spring and summer months (Dumbauld unpubl. data). Population surveys were conducted in April and September 2007, which allowed for comparison of growth and LF accumulation at the different sites over the growing season.

Statistical analysis: Potential outliers were identified by conducting an outlier analysis on untransformed data. Data points with studentized residuals $>4$ were removed, because it is likely these outlying points were a result of sample contamination during processing rather than real data values. A total of 23 data points were removed from the April samples, and 17 points were removed from the fall samples, represent- ing 5.1 and $3.8 \%$ of the data set, respectively. A 2-sample Kolomogrov-Smirnov (K-S) test was used to determine if the LF index and CL frequency distribution differed by sex. Variables that did not differ significantly between sexes were pooled for the MPA. All data were checked to determine if assumptions of normality and homoscedascity were met.

Age classes were identified with MPA of standard frequency histograms using both CL and LF data from all 3 sampling sites. Class intervals for lengthfrequency histograms were specified at $1 \mathrm{~mm}$ for both MIS and PR and at $0.75 \mathrm{~mm}$ for IF. Because animals were smaller at IF, a size class interval of $0.75 \mathrm{~mm}$ was selected. Optimal bin sizes produced multiple visually resolvable modes in frequency histograms without losing too much information from binning data. Class interval for the LF index-frequency distributions was specified at $0.1 \mathrm{ng} \mathrm{LF}$ content $\mathrm{\mu g}^{-1}$ protein for all 3 populations. Age classes were assigned to modes and calibrated based on average CL and the mean LF index of the 'reference age' $2+$ cohort determined in the growth experiment. Once age classes were identified from frequency data, estimated ages were assigned to CL and LF index values $( \pm 2 \mathrm{SD})$ from the mean for each mode. For modes that were overlapping, a normal probability distribution function (Sokal \& Rohlf 1995) was used to determine appropriate cut-off values for age assignments. A chi-square test for goodness-of-fit was used to determine if actual frequencies for estimated age classes conformed with the frequencies resulting from the MPA. A 1-sample K-S test was used to determine if age groupings were normally distributed for each mode. Other than the assignment of the age $2+$ cohort, the age-structure analysis was conducted independently of the growth study described above.

The LF accumulation rate was determined for each site surveyed using linear least-squares regression of the LF index value against LF-estimated age determined from the MPA. Multiple linear regression was used to test for significant differences in pigment accumulation among sites for both the spring and fall samples. Interaction terms were included in multiple regression models to determine if slopes for each site were significantly different from each other. After testing for differences among sites, data from all 3 sites were pooled to build a single, predictive, age-based model for LF accumulation. The LF accumulation model was then used to predict age based on the LF index value. Linear and Von Bertalanffy growth models were fit to size-at-age data to determine which model best described growth for the 3 populations assessed (Eq. 2, Von Bertalanffy Growth Function, VBGF):

$$
L_{t}=L_{\infty}\left(1-\mathrm{e}^{-\mathrm{k}(\mathrm{t}-\mathrm{t} 0)}\right)
$$




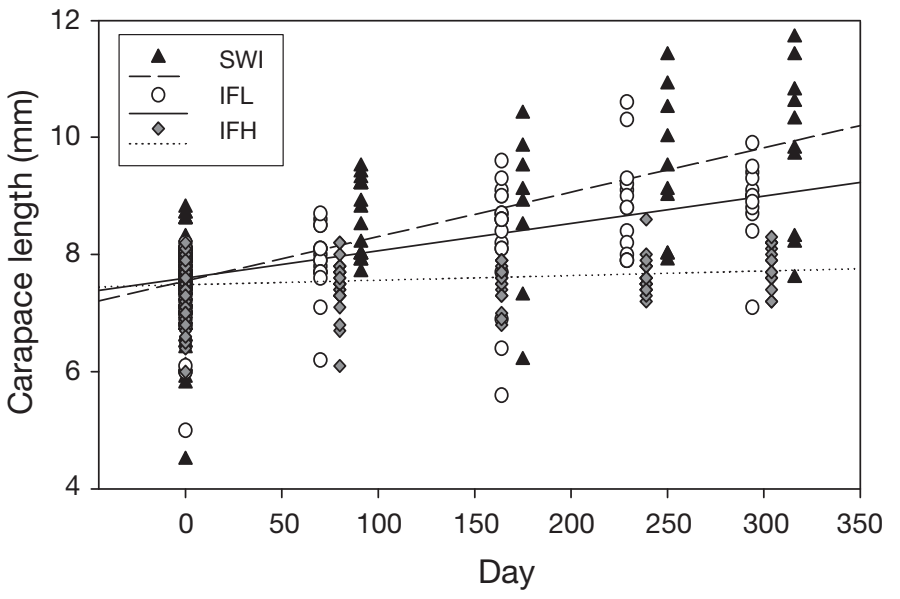

Fig. 3. Neotrypaea californiensis. Results of multiple linear regression analysis showing differences in growth rate of a cohort planted across 3 sites (SWI, IFL, IFH) in Yaquina Bay, OR. Each data point represents the body size measurement for an individual shrimp at a site for each sampling period. The initial sample $(t=0)$ was distributed among all sites to monitor growth overtime. Comparison of regression lines indicates statistically different slopes for each site. See Fig. 1 for site abbreviations

where $L_{t}$ is body length at age $t(\mathrm{yr}), L_{\infty}$ is asymptotic body length, $k$ is the growth constant and $t_{0}$ is the theoretical age at which $L_{t}=0 \mathrm{~mm}$.

\section{RESULTS}

\section{Verification of LF-based aging}

Regression analyses of data from the field growth experiment showed significant increases in average body size of the shrimp Neotrypaea californiensis from SWI and IFL during the $10 \mathrm{mo}$ study. CL at IFL and SWI increased 17.3 and $30.5 \%$, respectively. There was very little increase in body size at the IFH site, average only $4.5 \%$ (Fig. 3). Slopes of the regression lines from each site were significantly different, indicating differences in growth rate among sites (Table 2). The average LF index also increased at each site during the 10 mo study. The initial sample collected in July 2007 had an average LF index of 0.37 $\pm 0.14 \mathrm{ng} \mathrm{LF} \mu \mathrm{g}^{-1}$ protein. These animals were assumed to be age 2+, which means that they would have recruited to the benthos in fall 2004. Subsamples of shrimp from each site showed that the LF index increased

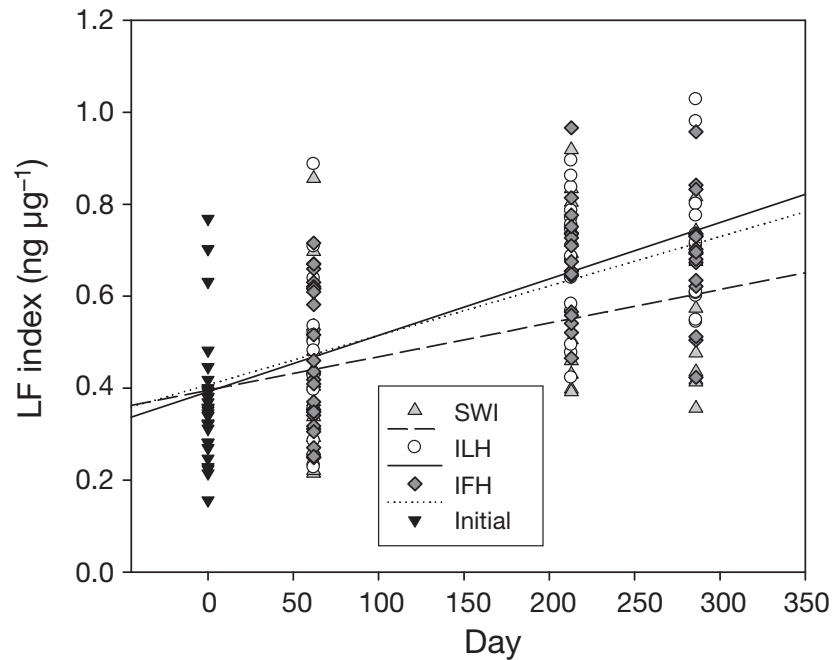

Fig. 4. Neotrypaea californiensis. Results of multiple linear regression analysis showing a positive relationship between the lipofuscin (LF) index and time (day) from 3 sites (SWI, IFL, IFH) in Yaquina Bay, OR. Data points represent LF index values for individual shrimp at specific sites for each sampling period. Slopes of regression lines were not significantly different from each other at the $95 \%$ confidence level. No LF data were collected between Days 62 and 212 because contaminated solvents were used in LF extraction for the second bucket sampled. See Fig. 1 for site abbreviations

over the 10 mo of the experiment. The average LF index increases of 51, 94 and $86 \%$ at SWI, IFL and IFH, respectively, were not significantly different at the $95 \%$ confidence level (Fig. 4, Table 2). Although not significantly different, animals at SWI showed a slower rate of LF accumulation than was observed at the Idaho Flats study sites. Sample sizes from SWI were smaller because of increased mortality $(M=$ $66 \%$ ) in cages at that site, which may have affected

Table 2. Neotrypaea californiensis. Results of regression analysis examining effects of time and site on body size (carapace length, $\mathrm{mm}$ ) and the lipofuscin (LF) index (ng LF $\mu^{-1}$ protein). N: Number of individuals included in the analysis. SWI: Seawall Island; IFH: Idaho Flats High; IFL: Idaho Flats Low; Z: slope comparison among sites; NS: not significant ( $p>0.05$ )

\begin{tabular}{|lccccc|}
\hline Regression & $\begin{array}{c}\text { Slope } \\
\text { (mean } \pm \text { SE) }\end{array}$ & $\begin{array}{c}\text { Intercept } \\
\text { (mean } \pm \text { SE) }\end{array}$ & adj. $\mathrm{R}^{2}$ & $\mathrm{p}$ & $\mathrm{N}$ \\
\hline Size vs Time & & & & & \\
SWI & $0.0076 \pm 0.0006$ & $7.55 \pm 0.069$ & 0.48 & $<0.001$ & 162 \\
IFH & $0.0008 \pm 0.0003$ & $7.48 \pm 0.035$ & 0.04 & 0.005 & 198 \\
IFL & $0.0047 \pm 0.0005$ & $7.60 \pm 0.072$ & 0.34 & $<0.001$ & 134 \\
$Z$ & & & & $<0.001$ & \\
LF vs Time & & & & & \\
SWI & $0.0008 \pm 0.0002$ & $0.38 \pm 0.027$ & 0.23 & $<0.001$ & 62 \\
IFH & $0.0011 \pm 0.0001$ & $0.38 \pm 0.021$ & 0.47 & $<0.001$ & 88 \\
IFL & $0.0013 \pm 0.0002$ & $0.38 \pm 0.024$ & 0.49 & $<0.001$ & 72 \\
$Z$ & & & & NS & \\
\hline
\end{tabular}


the results of the regression through sampling error. Regression analysis of pooled LF index data from all 3 sites showed the LF accumulation rate to be 0.0010 $\pm 0.0001 \mathrm{ng}^{-1} \mathrm{~g}^{-1} \mathrm{~d}^{-1}\left(\mathrm{p}<0.001, \mathrm{r}^{2}=0.37, \mathrm{n}=166\right)$, corresponding to an extrapolated annual accumula-

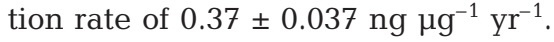

Average temperature at IFH and IFL was $3.15^{\circ} \mathrm{C}$ higher between July and September and $1^{\circ} \mathrm{C}$ lower during winter (November to March) than at SWI (Fig. 5). Shrimp populations at each site, however, routinely experienced from 8 to $9^{\circ} \mathrm{C}$ change in temperature over a single tidal cycle.

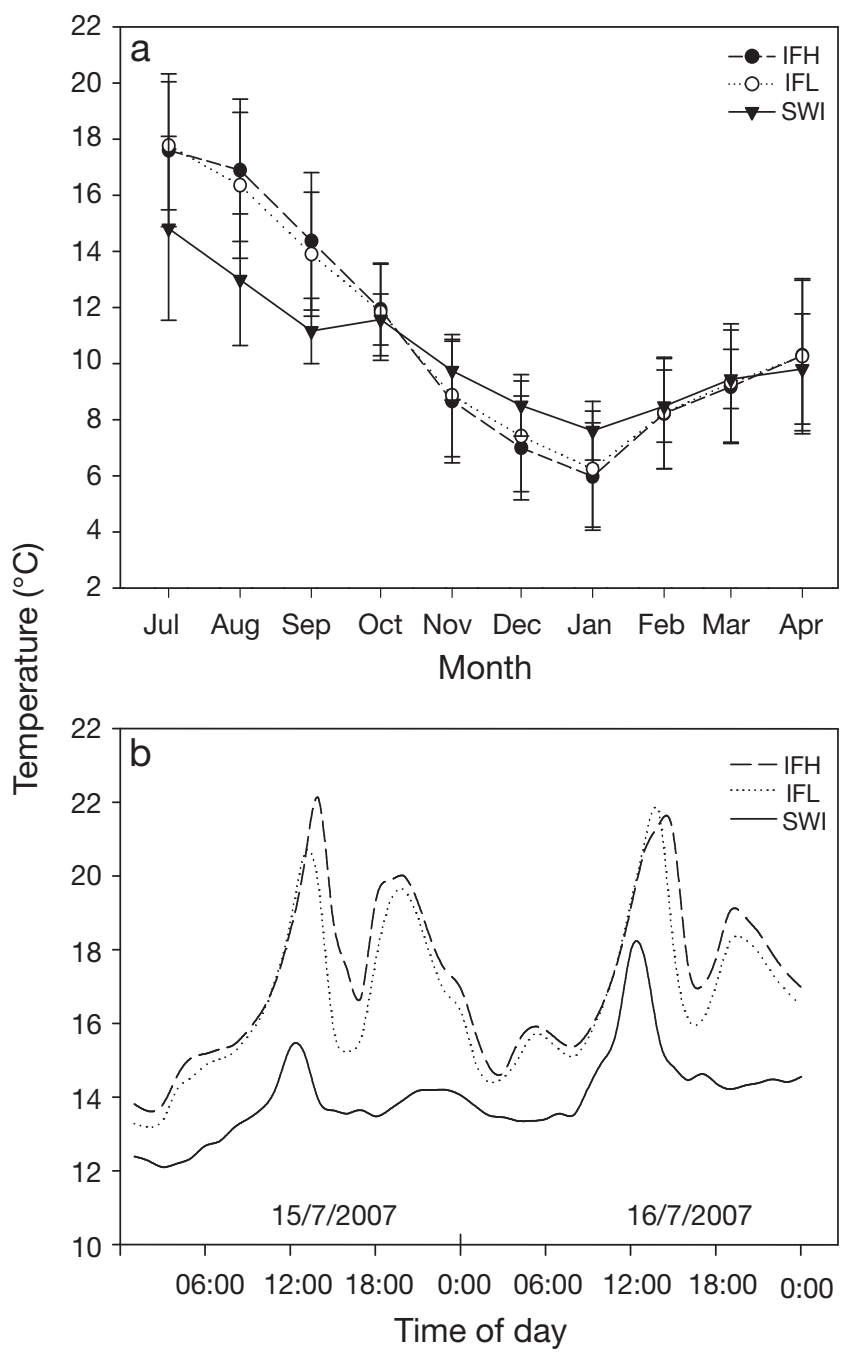

Fig. 5. Average temperature fluctuations at 3 sites (IFH, IFL, SWI) in Yaquina Bay, OR. (a) Monthly temperature at $10 \mathrm{~cm}$ below the sediment surface from July 2007 to April 2008 (means $\pm \mathrm{SD}$ ). (b) Temperature fluctuations experienced at all 3 study sites over 2 tidal cycles in July 2007: hourly temperature readings taken $10 \mathrm{~cm}$ below the sediment surface on 15 and 16 July 2007. Maximum change in temperature over the tidal period was $9.49^{\circ} \mathrm{C}$ at IFH. See Fig. 1 for site abbreviations

\section{Age structure analysis}

Comparison of size-frequency histograms (Fig. 2) showed that the CL of males and females were different at all 3 sites for both sampling periods (K-S test, $\mathrm{p}$ $>0.05$ in all cases). Length data for each sex were treated separately for modal progression analyses. Comparison of LF index-frequency data showed no significant differences between sexes; therefore, LF indices were pooled for all subsequent analyses (K-S test, $\mathrm{p}<0.05$ in all cases).

In CL-frequency histograms from the April survey, 5 to 7 highly resolved modes were detected (Table 3 ). In some cases, a separation index less than the critical value of 2 suggested significant overlap in the modes. Progression analysis of CL data from the September survey detected between 4 and 6 normal components in each distribution. All but 2 cases produced highly resolved modes, with separation indices greater than the critical value of 2. Modal progression analysis of LF index data revealed several more age classes than determined from CL data at all sites, for both the fall and spring sampling periods (Fig. 6, Table 4). At the PR site, 9 age classes were observed in the April sample and 10 in the September sample. Age 4+ in the spring sample was the only mode that showed significant overlap with adjacent age classes. At MIS, 7 age classes were observed in both fall and spring samples, all of which showed strong separation (Table 4). The population at IF produced the most age groupings, with 13 separate age classes comprising the frequency distribution from the fall sample. The spring sample at IF revealed 10 age classes, with statistically significant separation of groupings (Table 4).

Age classes were missing from the overall age structure in the 3 populations surveyed. These missing age classes tended to be on the extreme ends of the age distribution. Age cohorts $1+$ and 2+ were weak or absent in all 3 populations, and cohorts $4+$ and $5+$ were the strongest at all sites. Numbers-at-age were lowest in the older age classes, as would be expected because of natural mortality. At MIS, no significant groups were found beyond age $7+$. The spring sample from MIS showed 5 individuals with LF index values $>1.8 \mathrm{ng}$ $\mu^{-1}$ (Fig. 6). These animals did not form groups in the MPA, but age estimates calculated with the LF-based age model indicated animals up to $13 \mathrm{yr}$ old in the sample.

Regression analyses of the LF index with LF-estimated age showed a strong linear trend in LF accumulation in the 3 populations surveyed for both spring and fall samples. Multiple linear regression of spring survey data showed that the slopes and intercepts from the 3 sites were not significantly different from each 
other, so all LF index-at-age data were pooled for spring (Table 5). Analysis of fall survey data showed site to be a significant factor, but slopes were not different when compared among sites (Table 5). The LF index increased $0.20 \pm 0.07 \mathrm{ng} \mathrm{\mu g}^{-1}$ at PR over the summer growing season, and the average LF index at MIS and IF increased $0.18 \pm 0.04$ and $0.16 \pm 0.07 \mathrm{ng}^{\mathrm{N} \mathrm{g}^{-1}}$, respectively. The increases in the mean LF index from spring to fall were not significantly different among cohorts (ANOVA, $\mathrm{p}=0.135, \mathrm{n}=19, \mathrm{df}=8$ ) or among sites (ANOVA, $\mathrm{p}=0.418, \mathrm{df}=2$, $\mathrm{n}=19$ ). The daily rate of LF accumulation averaged among all 3 sites was $0.0011 \mathrm{ng} \mathrm{LF} \mu^{-1}$ protein $\mathrm{d}^{-1}$ over the summer growing season, an estimate comparable to what was determined in the field growth experiment.

Comparing LF-based age estimates to those determined from analysis of CL data showed size-at-age to vary within populations. When LF-frequency histograms from the April survey collection were overlaid with size classes, as determined from modal progression analysis of carapace length data, each mode was composed of individuals from a number of different size classes (Fig. 7). The largest specimens at PR were grouped in age $7+$ based on $C L$, but they were in the age $4+$ age class as determined according to the LF index value. Conversely, a number of small shrimp (size groups $2+$ and $3+$ based on CL) were grouped with older age classes determined according to LF indices. Variation in size-at-age was observed for all 3 populations sampled.
Table 3. Neotrypaea californiensis. Age structure estimated by modal progression analysis of length-frequency data from both spring and fall surveys. SD: standard deviation; $\mathrm{N}$ : number of individuals included in the analysis; SI: separation index; NS: not significant; NA: not applicable; -: no data

\begin{tabular}{|c|c|c|c|c|c|c|c|c|}
\hline \multirow{2}{*}{$\begin{array}{l}\text { Est. age } \\
\text { class }\end{array}$} & \multirow[b]{2}{*}{ Mean size } & \multicolumn{3}{|c|}{-Males } & \multicolumn{4}{|c|}{ _Females } \\
\hline & & $\mathrm{SD}$ & $\mathrm{N}$ & SI & Mean size & $\mathrm{SD}$ & $\mathrm{N}$ & SI \\
\hline \multicolumn{9}{|c|}{ Palix River } \\
\hline \multicolumn{9}{|c|}{ April } \\
\hline $2+$ & 6.60 & 0.08 & 5 & NA & 6.25 & 0.50 & 4 & NA \\
\hline $3+$ & 11.83 & 1.00 & 9 & 5.81 & 11.50 & 1.40 & 10 & 5.53 \\
\hline $4+$ & 14.23 & 0.51 & 7 & 3.18 & 17.66 & 1.24 & 28 & 4.67 \\
\hline $5+$ & 16.87 & 0.75 & 7 & 4.19 & 19.48 & 0.62 & 67 & NS \\
\hline $6+$ & 20.95 & 1.42 & 22 & 3.76 & - & - & - & - \\
\hline $7+$ & 22.29 & 0.54 & 22 & NS & - & - & - & - \\
\hline \multicolumn{9}{|c|}{ September } \\
\hline $1+$ & 6.00 & 0.5 & 2 & NA & - & - & - & - \\
\hline $2+$ & - & - & - & - & 10.02 & 1.03 & 4 & NA \\
\hline $3+$ & 13.96 & 1.22 & 23 & 9.24 & 14.34 & 0.86 & 12 & 4.57 \\
\hline $4+$ & 18.41 & 1.09 & 5 & 3.86 & 18.66 & 1.09 & 50 & 4.43 \\
\hline $5+$ & 22.07 & 0.5 & 14 & 4.60 & 19.86 & 0.05 & 33 & NS \\
\hline $6+$ & - & - & 21.73 & 0.50 & 1 & 3.74 & - & - \\
\hline \multicolumn{9}{|c|}{ Middle Island Sands } \\
\hline \multicolumn{9}{|c|}{ April } \\
\hline $2+$ & 6.33 & 0.50 & 3 & NA & - & - & - & - \\
\hline $3+$ & 9.99 & 0.63 & 5 & 6.48 & 9.28 & 1.69 & 4 & NA \\
\hline $4+$ & 14.51 & 1.16 & 29 & 5.05 & 13.11 & 1.04 & 30 & 2.81 \\
\hline $5+$ & 17.87 & 0.99 & 50 & 3.13 & 14.91 & 0.91 & 127 & NS \\
\hline \multicolumn{9}{|c|}{ September } \\
\hline $2+$ & 8.09 & 0.90 & 3 & NA & - & - & - & - \\
\hline $3+$ & 10.82 & 0.50 & 5 & 3.89 & 12.08 & 1.40 & 12 & NA \\
\hline $4+$ & 14.90 & 1.25 & 21 & 4.29 & 14.80 & 0.53 & 74 & 2.83 \\
\hline $5+$ & 18.06 & 0.77 & 13 & 3.44 & 16.01 & 0.50 & 9 & 2.37 \\
\hline \multicolumn{9}{|c|}{ Idaho Flats } \\
\hline \multicolumn{9}{|c|}{ April } \\
\hline $1+$ & 5.01 & 0.39 & 3 & NA & - & - & - & - \\
\hline $2+$ & 7.83 & 1.00 & 20 & 4.06 & 7.54 & 0.87 & 18 & NA \\
\hline $3+$ & 9.78 & 0.38 & 11 & 2.83 & 9.61 & 0.38 & 40 & 3.31 \\
\hline $4+$ & 11.35 & 0.97 & 57 & 2.33 & 10.53 & 0.38 & 86 & 2.42 \\
\hline $5+$ & 14.48 & 0.78 & 6 & 3.58 & 11.85 & 0.75 & 47 & 2.34 \\
\hline \multicolumn{9}{|l|}{ October } \\
\hline $1+$ & 6.50 & 0.83 & 7 & NA & 5.13 & 0.68 & 6 & NA \\
\hline $2+$ & 10.30 & 1.17 & 35 & 3.78 & 9.82 & 1.12 & 17 & 5.21 \\
\hline $3+$ & 12.30 & 0.69 & 18 & 2.15 & 10.91 & 0.77 & 132 & NS \\
\hline $4+$ & 13.48 & 0.38 & 5 & 2.21 & 12.94 & 0.40 & 9 & 3.47 \\
\hline $5+$ & 14.54 & 0.40 & 2 & 2.70 & - & - & - & - \\
\hline
\end{tabular}

\section{LF-based age model}

Pooled data from the April population survey were used to develop a single LF-based model for predicting age in Neotrypaea californiensis (Fig. 8), such that:

$$
\text { Age }(\mathrm{yr})=\frac{\left[\mathrm{LF} \text { index }\left(\mathrm{ng} \mu \mathrm{g}^{-1}\right)+0.064\right]}{0.21}
$$

The resulting model showed a positive relationship between the LF index and LF-estimated age $\left(R^{2}=0.92\right.$, $\mathrm{df}=1, \mathrm{n}=441, \mathrm{p}<0.001$ ). This model was used to calculate LF-based age estimates for all animals collected in the spring survey and then to compare body size with actual age at each site.

Linear and Von Bertalanffy growth models did not fit size-at-age data well. The linear model resulted in non-significant correlations of the variables (CL and LF-estimated age) for both sexes (Table 6, p > 0.05 in all cases). The Von Bertalanffy growth function was also insufficient in correlating body size to age (Fig. 9, Table 7). Size-at-age data from PR produced a significant model when fit to the VBGF; however, a weak correlation coefficient suggested a poor fit of the model to the data $\left(p=0.002, r^{2}=0.10\right)$. The asymptotic length 
Table 4. Neotrypaea californiensis. Age structure estimated by modal progression analysis of the lipofuscin (LF) index-frequency data from both spring and fall surveys. SD: standard deviation; N: number of analysed individuals; SI: separation index; NS: not significant; NA: not applicable

\begin{tabular}{|c|c|c|c|c|c|c|c|c|}
\hline $\begin{array}{l}\text { Est. } \\
\text { age class }\end{array}$ & $\begin{array}{l}\text { Mean LF } \\
\text { index }\end{array}$ & SD & $\mathrm{N}$ & SI & $\begin{array}{l}\text { Mean LF } \\
\text { index }\end{array}$ & SD & $\mathrm{N}$ & SI \\
\hline \multicolumn{9}{|c|}{ Palix River } \\
\hline \multicolumn{5}{|c|}{ April } & \multicolumn{4}{|l|}{ September } \\
\hline $2+$ & 0.30 & 0.05 & 2 & NA & 0.50 & 0.05 & 2 & NA \\
\hline $3+$ & 0.68 & 0.10 & 31 & 5.15 & 0.76 & 0.05 & 10 & 5.07 \\
\hline $4+$ & 0.83 & 0.09 & 44 & NS & 0.97 & 0.69 & 34 & 3.27 \\
\hline $5+$ & 0.99 & 0.05 & 26 & 2.54 & 1.19 & 0.09 & 37 & 2.88 \\
\hline $6+$ & 1.17 & 0.08 & 29 & 2.67 & 1.46 & 0.08 & 22 & 3.27 \\
\hline $7+$ & 1.50 & 0.09 & 12 & 3.71 & 1.72 & 0.12 & 17 & 2.56 \\
\hline $8+$ & 1.71 & 0.05 & 7 & 3.00 & 2.00 & 0.11 & 11 & 2.44 \\
\hline $9+$ & 2.00 & 0.05 & 3 & 5.88 & - & - & - & - \\
\hline \multirow{2}{*}{$10+$} & \multirow{2}{*}{\multicolumn{4}{|c|}{$\chi^{2}=4.0, \mathrm{df}=6, \mathrm{p}=\mathrm{NS}$}} & 2.60 & 0.05 & 1 & 7.94 \\
\hline & & & & & \multicolumn{4}{|c|}{$\chi^{2}=5.6, \mathrm{df}=6, \mathrm{p}=\mathrm{NS}$} \\
\hline \multicolumn{9}{|c|}{ Middle Island Sands } \\
\hline & \multicolumn{4}{|l|}{ April } & \multicolumn{4}{|l|}{ September } \\
\hline $2+$ & 0.37 & 0.05 & 5 & NA & - & - & - & - \\
\hline $3+$ & 0.53 & 0.06 & 14 & 2.9 & 0.68 & 0.05 & 10 & NA \\
\hline $4+$ & 0.70 & 0.05 & 26 & 3.01 & 0.91 & 0.10 & 28 & 3.07 \\
\hline $5+$ & 0.97 & 0.14 & 78 & 2.75 & 1.21 & 0.11 & 29 & 2.93 \\
\hline $6+$ & 1.32 & 0.07 & 18 & 3.33 & 1.48 & 0.06 & 20 & 3.24 \\
\hline \multirow[t]{2}{*}{$7+$} & 1.61 & 0.07 & 4 & 4.26 & 1.76 & 0.09 & 11 & 3.74 \\
\hline & \multicolumn{4}{|c|}{$\chi^{2}=2.13, \mathrm{df}=5, \mathrm{p}=\mathrm{NS}$} & \multicolumn{4}{|c|}{$\chi^{2}=1.88, \mathrm{df}=4, \mathrm{p}=\mathrm{NS}$} \\
\hline \multicolumn{9}{|c|}{ Idaho Flats } \\
\hline \multicolumn{5}{|c|}{ April } & \multicolumn{4}{|l|}{ October } \\
\hline $2+$ & 0.39 & 0.05 & 6 & NA & 0.2 & 0.05 & 1 & NA \\
\hline $3+$ & 0.60 & 0.07 & 16 & 3.45 & 0.64 & 0.09 & 6 & NA \\
\hline $4+$ & 0.78 & 0.09 & 66 & 2.23 & 0.91 & 0.06 & 12 & 3.60 \\
\hline $5+$ & 1.06 & 0.07 & 27 & 3.68 & 1.22 & 0.1 & 40 & 3.90 \\
\hline $6+$ & 1.26 & 0.06 & 16 & 3.06 & 1.46 & 0.07 & 12 & 2.33 \\
\hline $7+$ & 1.48 & 0.05 & 9 & 3.84 & 1.72 & 0.19 & 39 & 2.69 \\
\hline $8+$ & 1.73 & 0.05 & 4 & 4.98 & 1.95 & 0.08 & 21 & 2.33 \\
\hline $9+$ & - & - & - & - & 2.14 & 0.05 & 8 & 2.30 \\
\hline $10+$ & 2.30 & 0.08 & 3 & 8.71 & 2.41 & 0.05 & 8 & 3.74 \\
\hline $11+$ & & & & & 2.65 & 0.1 & 6 & 3.37 \\
\hline \multirow[t]{2}{*}{$13+$} & \multirow{2}{*}{\multicolumn{4}{|c|}{$\chi^{2}=5.21, \mathrm{df}=6, \mathrm{p}=\mathrm{NS}$}} & 3.16 & 0.08 & 5 & 5.76 \\
\hline & & & & & \multicolumn{4}{|c|}{$\chi^{2}=8.61, \mathrm{df}=9, \mathrm{p}=\mathrm{NS}$} \\
\hline
\end{tabular}

length measurements (Dumbauld et al. 1996). Results from a 10 mo field growth experiment showed that the LF index was correlated with time and not body size, verifying the validity of using the biochemical aging technique. Demographic assessments revealed significant differences in growth rate among spatially separated populations of ghost shrimp both within and among estuaries. Despite differences in growth, LF accumulation rate was not different among the study sites, indicating that the LF index is a better predictor of chronological age than carapace length. The shortterm nature of the growth study allowed verification of only 1 yr of LF accumulation to be documented at multiple sites. In the future, a longterm verification experiment would be useful for estimating the trajectory of LF accumulation over a multi-year span.

Until now, much has remained unknown about the longevity of Neotrypaea californiensis. Early studies investigating the ecology of the ghost shrimp led to the belief that it was a long-lived species, possibly living up to 10 or more years of age (MacGinitie 1935). MacGinitie (1934) also suggested that the rare occurrence of juveniles in Elkhorn Slough near Monterey Bay, California, combined with little to no year-class groupings among and growth coefficients from the 3 populations assessed varied greatly. At IF in Yaquina Bay, the asymptotic length was $10.4 \mathrm{~mm}$. This value was $43 \%$ smaller than what was observed for the PR population in Willapa Bay $\left(L_{\infty}=18.5\right)$. The population at MIS showed an intermediate asymptotic length $\left(L_{\infty}=14.8\right)$.

\section{DISCUSSION}

The work presented in the current study demonstrates the feasibility and practicality of using the biochemical methods of LF quantification developed by $\mathrm{Ju}$ et al. (1999) to assess age in the ghost shrimp Neotrypaea californiensis. Previous estimates of age for this crustacean had only been made using body-
Table 5. Neotrypaea californiensis. Results of multiple linear regression of the mean lipofuscin (LF) index and site against LF-estimated age for 2 sampling periods. SE: standard error; $Z$ : comparison of regression lines; NS: not significant

\begin{tabular}{|lcccc|}
\hline Variable & Estimate & SE & $t$ & $\mathrm{p}$ \\
\hline Spring & & & & \\
Constant & -0.163 & 0.045 & -3.62 & 0.002 \\
Age & 0.236 & 0.006 & 41.11 & $<0.001$ \\
Site & 0.011 & 0.015 & 0.07 & 0.463 \\
$Z$ & & & $\mathrm{NS}$ \\
SE of estimate $=0.061, \mathrm{R}^{2}=0.99, \mathrm{df}=2, \mathrm{p}<0.001$ & \\
Fall & & & \\
Constant & 0.018 & 0.025 & 0.75 & 0.463 \\
Age & 0.250 & 0.003 & 89.78 & $<0.001$ \\
Site & -0.034 & 0.009 & -3.61 & 0.002 \\
$Z$ & & & $\mathrm{NS}$ \\
SE of estimate $=0.039, \mathrm{R}^{2}=0.99, \mathrm{df}=2, \mathrm{p}<0.001$ & \\
\hline
\end{tabular}



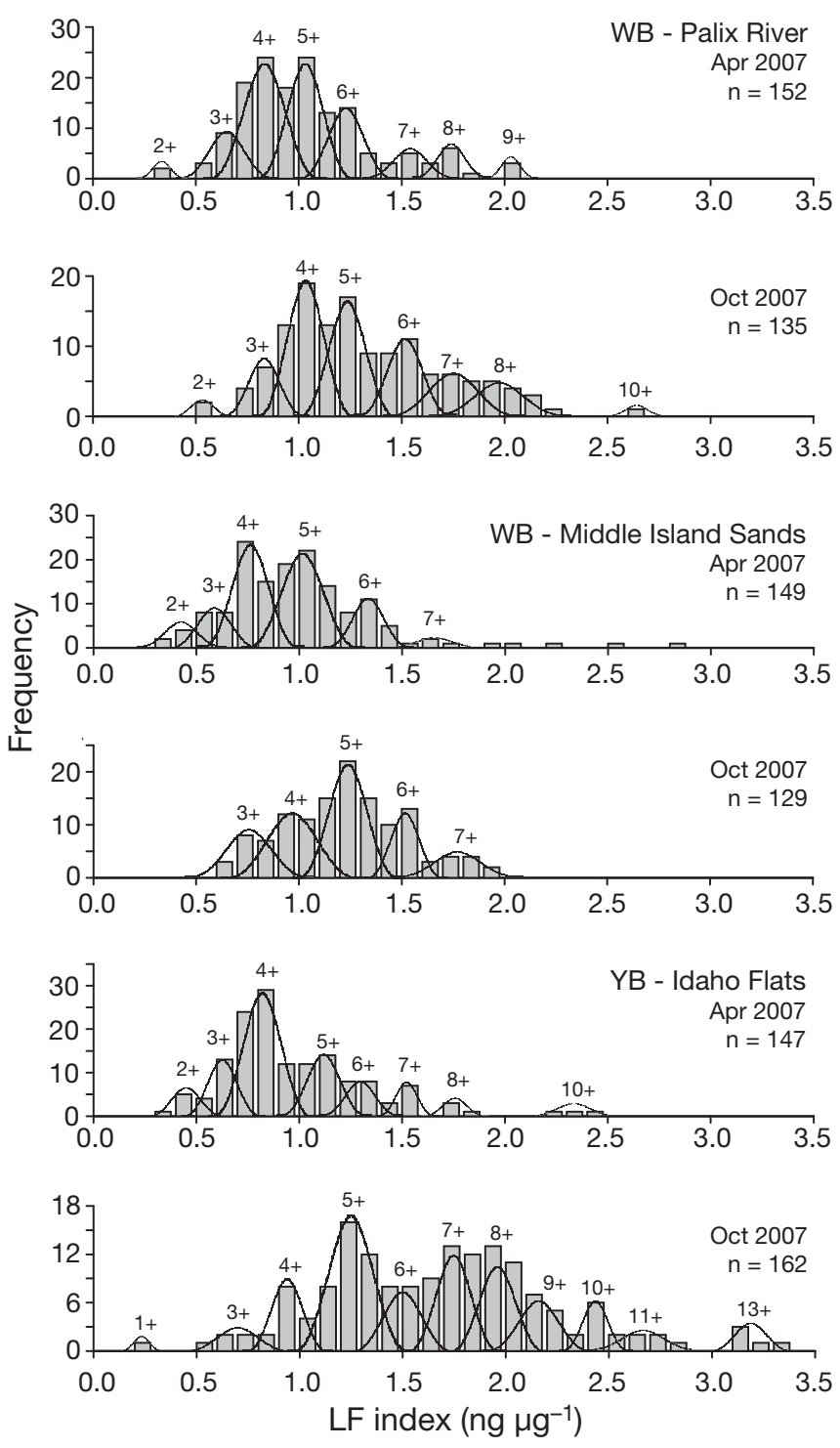

Fig. 6. Neotrypaea californiensis. Results of modal progression analysis of the lipofuscin (LF) index data from spring and fall 2007. Age classes were calibrated based on the average LF index from the 'reference age class' determined in the field growth experiment. See Fig. 1 for site abbreviations

individuals and low mortality of established adults, was evidence that the species was long-lived. More recent studies used size-frequency data to estimate growth and the number of age classes in several Oregon and Washington populations, suggesting the animal lives to be from 3 to 5 yr old (Bird 1982, Dumbauld et al. 1996). Annual larval recruitment of the shrimp to Willapa Bay has been shown to be variable, and recent studies hint at the possibility of missing size/year classes (Dumbauld et al. 2006). In the current study, assessment of population age structure using analysis of LF as an age biomarker was successful in resolving up to 13 separate age classes in Yaquina Bay and 9 age
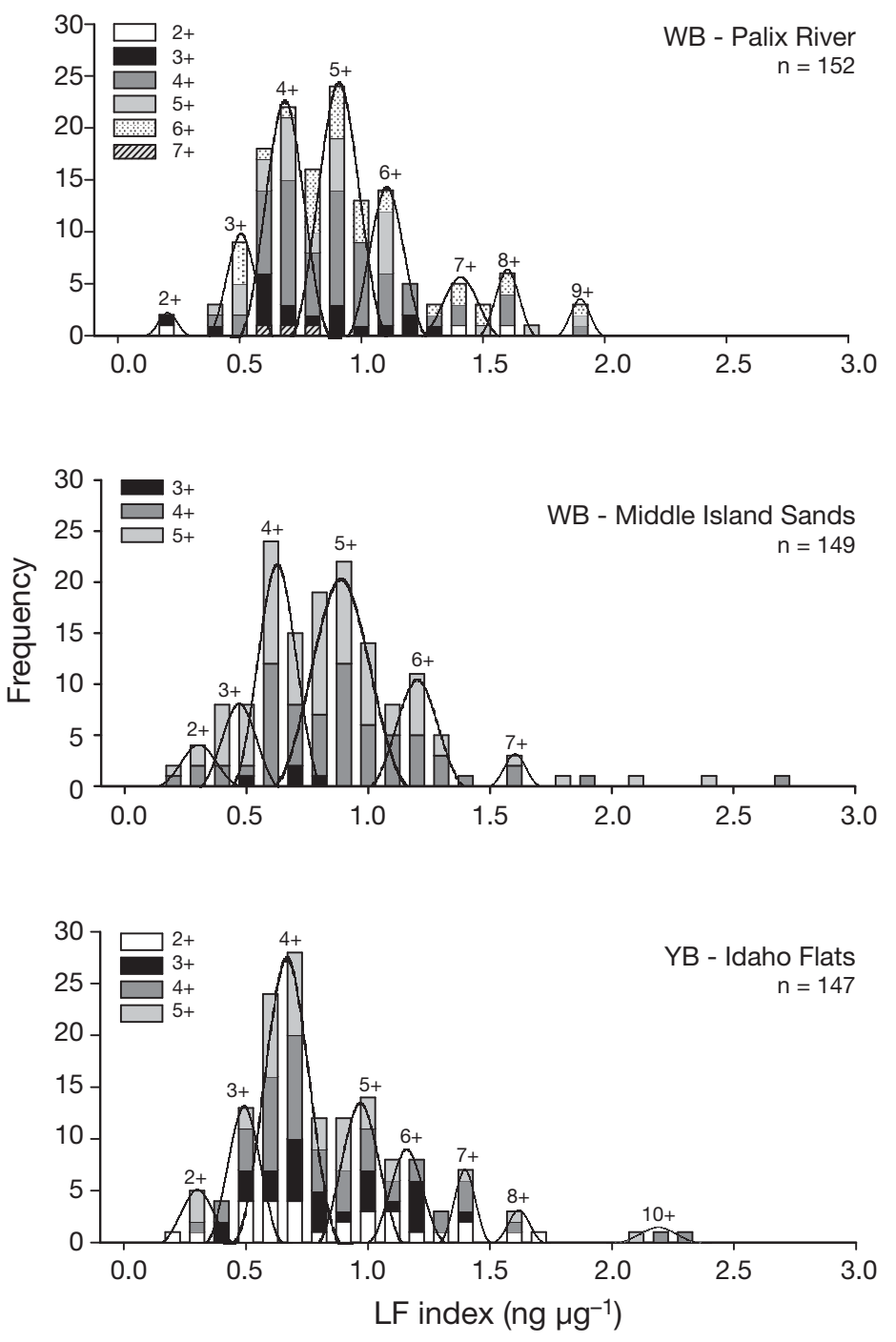

Fig. 7. Neotrypaea californiensis. Lipofuscin (LF) indexfrequency histograms from April 2007, with bars representing age classes as determined from modal progression analysis of carapace length-frequency histograms

classes in Willapa Bay. These results support the earlier speculation that the species can live for up to 10 or more years.

The estimate for average annual LF accumulation rate in Neotrypaea californiensis determined through analysis of age structure was lower than the annual rate that can be extrapolated from the field growth experiment (Fig. 8). Because of the short-term nature of the present study, the growth and LF accumulation data presented here represent only a single year and growth season. It is possible that the environmental conditions during the summer of 2007 were such that LF accumulation rates were relatively high. In the current study, the analysis of age structure showed LF increased $0.0012 \pm 0.0001 \mathrm{ng} \mathrm{LF} \mu^{-1}$ protein $\mathrm{d}^{-1}$ between April and 


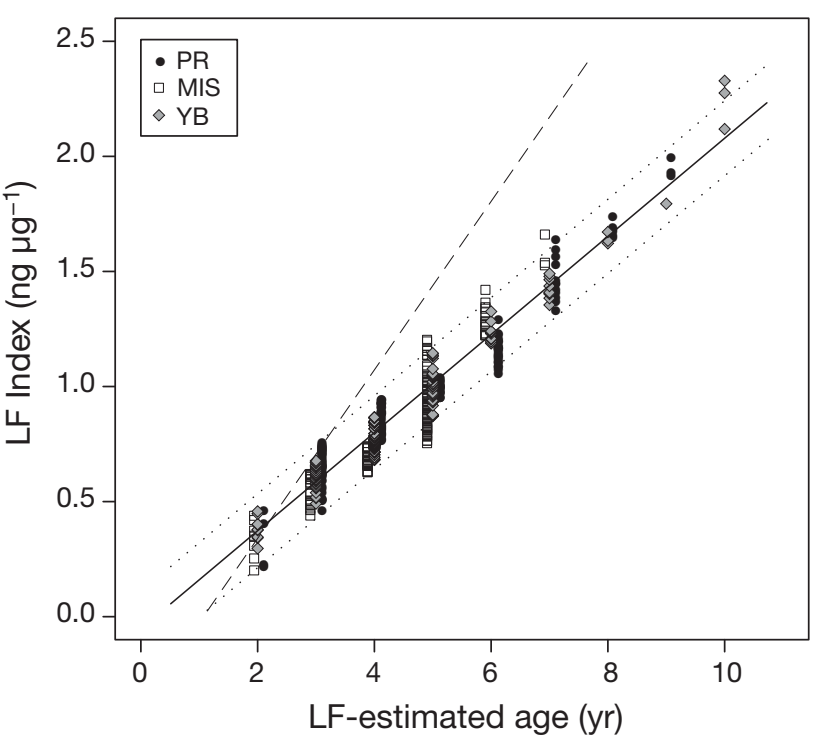

Fig. 8. Neotrypaea californiensis. LF-based age model for populations in Willapa Bay, WA, and Yaquina Bay, OR. Model was constructed from pooled LF data from the April survey collection. Solid line represents the LF accumulation model with $95 \%$ prediction intervals (dotted lines) $\left(\mathrm{R}^{2}=0.92, \mathrm{df}=1\right.$, $\mathrm{n}=443, \mathrm{p}<0.001)$. The dashed line represents extrapolated annual LF accumulation rate from the short-term growth study $($ Age $=($ LF index +0.365$) / 0.365)$

Table 6. Neotrypaea californiensis. Results of multiple linear regression of size to lipofuscin-estimated age for both sexes. SE: standard error; $Z$ : comparison of regression slopes; NS: not significant

\begin{tabular}{|lccccc|}
\hline Site & $\begin{array}{c}\text { Slope } \\
\text { (mean } \pm \text { SE) }\end{array}$ & $\begin{array}{c}\text { Intercept } \\
\text { (mean } \pm \text { SE) }\end{array}$ & $\mathrm{r}^{2}$ & $\mathrm{p}$ & $\mathrm{N}$ \\
\hline Palix River & & & & & \\
Male & $0.37 \pm 0.34$ & $16.56 \pm 1.67$ & 0.021 & 0.27 & 58 \\
Female & $0.34 \pm 0.20$ & $15.81 \pm 0.99$ & 0.032 & 0.08 & 94 \\
$Z$ & & & & $\mathrm{NS}$ & \\
Middle Island Sands & & & & \\
Male & $-0.02 \pm 0.13$ & $16.12 \pm 0.72$ & 0.006 & 0.87 & 49 \\
Female & $-0.06 \pm 0.08$ & $14.42 \pm 0.37$ & 0.050 & 0.50 & 100 \\
$Z$ & & & & $\mathrm{NS}$ & \\
Idaho Flats & & & & & \\
Male & $-0.13 \pm 0.19$ & $11.14 \pm 0.95$ & 0.100 & 0.52 & 45 \\
Female & $0.02 \pm 0.09$ & $10.15 \pm 0.43$ & 0.004 & 0.85 & 102 \\
$Z$ & & & & NS & \\
\hline
\end{tabular}

September of 2007. The growth study took place during the same year and produced a similar daily LF accumulation rate. When averaged over a lifespan, natural variability in LF accumulation may produce a lower annual rate, similar to that generated by the LF-age model constructed from population age structure (Fig. 8). Seasonal fluctuation in LF accumulation may also explain the observed discrepancy in annual LF accumulation rates. The growth study took place over a 10 mo period, which
Table 7. Neotrypaea californiensis. Parameter estimation for the Von Bertalanffy growth function (Eq. 2) modeled by sizeat-age for each survey site. $L_{\infty}$ : asymptotic length $(\mathrm{mm}) ; K$ : annual growth coefficient $\left(\mathrm{yr}^{-1}\right)$. The parameter $t_{0}$ was constrained to equal zero

\begin{tabular}{|lcccc|}
\hline Site & $L_{\infty}(\mathrm{mm})$ & $K$ & $\mathrm{r}^{2}$ & $\mathrm{p}$ \\
\hline Palix River & 18.5 & 0.81 & 0.10 & 0.002 \\
Middle Island Sands & 14.8 & 2.88 & 0.01 & 0.670 \\
Idaho Flats & 10.4 & 1.57 & 0.01 & 0.320 \\
\hline
\end{tabular}

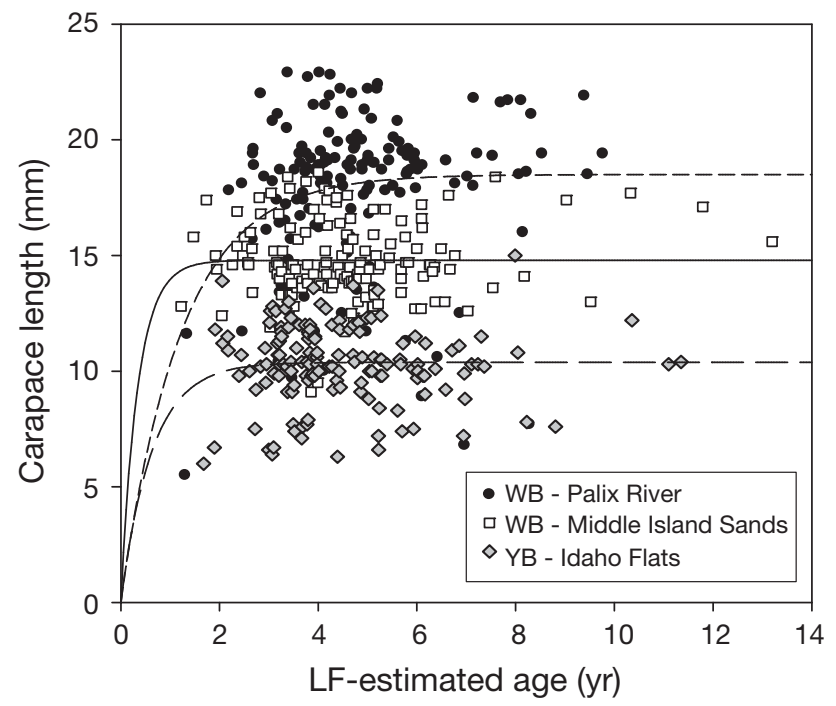

Fig. 9. Neotrypaea californiensis. Scatterplot showing the relationship between carapace length to lipofuscin (LF)-estimated age. Ages were calculated from the LF-based age model (Eq. 1). Regression lines represent Von Bertalanffy growth model fit to the data

included the summer growing season. Other studies investigating LF increase have shown seasonal fluctuations in accumulation, with the highest rates occurring during summer months (Sheehy et al. 1994, Ju et al. 1999, Vila et al. 2000, Kodama et al. 2006). It is possible that the greatest rate of pigment accumulation in N. californiensis also occurs during the summer months when the growth rate is high. Incorporating seasonal variation in the LF-age model would increase precision of the LF accumulation model and allow for greater accuracy in estimating actual age.

The LF-age model presented in the current study represents a $10 \mathrm{yr}$ average of LF accumulation, which integrates the fine-scale variability in LF accumulation rate that may be environmentally influenced. The accuracy of the current model is based on the assumption that animals with an LF index value of $0.37 \pm 0.14$ are age $2+$. Scarcity of young animals and difficult culturing Neotrypaea californiensis in the laboratory have 
made growth studies impossible and assigning the 'reference cohort' based on previous size-at-age designations provides only a rough estimation of true age. It is possible that the $2+$ cohort was incorrectly assigned. In addition, the reference age class in the field growth experiment showed variable LF accumulation. This variability could have resulted from the reference age class being comprised of multiple true age classes. Despite these challenges, ages estimated from LF represent a vast improvement over those determined from analysis of length-frequency data, where the error in age estimates can be much greater. The precision and accuracy of the LF-age model should be tested and improved by conducting long-term experiments to monitor the LF accumulation rate in known-age animals over time. Incorporating seasonal and interannual variability in LF accumulation rate into the model in the future could increase the precision of age estimates to a time-scale of months, which would be beneficial for modeling important biological processes like the timing of recruitment and maturity.

Population age structure, year-class strength and life expectancy are parameters that can be used to estimate annual recruitment of a species when young-ofyear are scarce or difficult to sample (Hilborn \& Walters 1992). The current monitoring program for IPM of ghost shrimp involves conducting annual surveys to estimate population density and annual recruitment in multiple West Coast estuaries (Dumbauld et al. 2006). Strong recruitment of Neotrypaea californiensis in the early 1990s is evident from the long-term yearly monitoring data from the Palix River in Willapa Bay (Feldman et al. 2000). Since that time, recruitment has been relatively low and population density has correspondingly declined (Dumbauld et al. 2006). However, LF-based age structure from the current study indicates that at least 9 age classes in the present population at the Palix River show 4 and 5 yr old shrimp predominating (Fig. 6). The current method of recruit sampling involves haphazard sampling of ghost shrimp beds during the fall, slightly after recruitment to the benthos is thought to occur. This method of recruitment sampling could be biased in one or more of the following ways: (1) recruitment is actually more disperse so that by chance juveniles are not captured in the samples taken, (2) recruitment occurs in areas that are not routinely sampled and (3) recruitment occurs well before or after the current sample timing so that shrimp are either not present or have burrowed to a greater depth and are missed. These biases may lead to a discrepancy between the results of recruitment sampling and cohort analysis. Dumbauld et al. (2006) argued that developing a technique to hind-cast shrimp recruitment will be an important aspect of a successful IPM plan. LF-based age determination pro- vides a valuable tool to cross-check and assess recruitment history in $N$. californiensis, particularly when sampling methods are unable to capture the current year class. LF-based aging may provide a better longterm estimate of recruitment success and more accurate estimations for numbers-at-age, allowing researchers studying population dynamics and life history to correlate environmental factors, such as upwelling index, with recruitment success and to determine if populations are sustained by infrequent but strong recruitment events or a continuous low level of recruitment.

Results from both the out-planting experiment and age-structure analyses showed significant variation in growth rate both within and among ghost shrimp populations. Von Bertalanffy and linear growth models did not adequately describe the relationship of age and size for any of the 3 Neotrypaea californiensis populations surveyed. A significant amount of scatter was associated with each model, which resulted in a weak correlation between the 2 variables for a given site. This type of weak correlation of size and true age has been demonstrated in other long-lived crustaceans, including the western rock lobster Panulirus cygnus (Sheehy et al. 1998) and the European lobster Homarus gammarus (Sheehy et al. 1996, Sheehy \& Bannister 2002). Long-lived animals experience a wide range of environmental conditions over a lifespan and, therefore, tend to exhibit a broad range of sizes within an age class. For ghost shrimp, it appears that most of their growth occurs during the first $2 \mathrm{yr}$ after recruitment. Most animals have reached a size approaching the $L_{\text {? }}$ estimate for a site by the time they reach $2+\mathrm{yr}$ old. However, young animals $(<2+$ yr) are poorly represented in our data set, making it difficult to draw conclusions about growth in $N$. californiensis during the first 2 yr. Rearing experiments are commonly used to determine juvenile growth rate and to investigate factors controlling growth during the first 2 years. Weak recruitment of $N$. californiensis and difficulties in culturing these shrimp have created challenges for conducting these experiments to investigate growth.

Temperature and food supply are the most important factors controlling crustacean growth (Hartnoll 1982, 2001). For poikilothermic animals that gain thermal energy from the surrounding environment, elevated temperatures may cause an increase in metabolism and therefore an increase in growth rate (Sohal 1981, Hartnoll 1982, Sheehy et al. 1995). In the current study, the average LF index did not vary significantly among study sites. Although animals at SWI experienced the lowest mean temperature during the growing season (July to October), the average body size increased nearly twice that of animals from IFL. Newell (1969) reviewed the effect of fluctuation in temperature on 
the metabolism of intertidal invertebrates and concluded that metabolic rate is relatively independent of temperature for most intertidal species. Similarly, Wahle et al. (1996) showed that metabolic rate in the lobster Homarus americanus was not reflected in growth and suggested that energy may be reallocated from growth to other physiological functions, while maintaining an overall static metabolic rate. $N$. californiensis encounters a wide range of thermal conditions throughout the year at the intertidal sites it inhabits. These animals may have adapted by adopting temperature-independent metabolic pathways.

While temperature may not be a major factor influencing growth in Neotrypaea californiensis, food availability and density dependence likely play greater roles. Food supply can influence crustacean growth, affecting both the maximum size attained and the growth rate (Ingle et al. 1937, Mason 1963, Hartnoll 1982, Gu et al. 1996). In the present study, sites that were located closest to the mouth of the estuary (SWI and PR) exhibited the highest growth rates. These sites were presumably exposed to the coastal marine water mass for longer periods than those in the upper estuary and would have received greater food resource availability during the growing season. Benthic sources may also be important components of the ghost shrimp's diet. Studies examining the food sources of other thalassinidean shrimps have shown seagrasses and their attached epiphytes to be significant sources of organic carbon, as well as benthic algae (Boon et al. 1997, Abed-Navandi \& Dworschak 2005). Burrow morphology suggests that $N$. californiensis is a deposit feeder that feeds primarily on detritus sifted from the substrate (Griffis \& Suchanek 1991). No studies have yet been conducted to examine the importance of different food sources on growth in $N$. californiensis. Detailed trophic studies are required to determine the major components of the ghost shrimp's diet and how the abundance of those food sources varies spatially and temporally in Pacific Northwest estuaries.

Density-dependant factors may also play an important role in determining the rate of growth at a given site. The effect of stocking density on crustacean production has been extensively studied in the context of commercial aquaculture. Most of these studies have found the growth rate to be inversely related to stocking density, even when food was not a limiting factor (Lutz \& Wolters 1986, D'Abramo et al.1989, NaranjoPáramo et al. 2004). The 3 locations we surveyed exhibited different population densities. Animals at IF were small relative to those at the 2 sites in Willapa Bay and had an $\sim 70 \%$ greater population density. LFbased age structure showed the population at IF to have the most age classes and the smallest mean size. Low food supply coupled with high densities of shrimp may explain the slower growth and smaller size of shrimp found in the upper estuary. An explicit investigation into the effect of intraspecific competition with replicated treatment density would also provide valuable information regarding growth rates in these deposit-feeding shrimp, which are generally found in dense populations.

Clearly, there are many factors that could limit growth in Neotrypaea californiensis. Greater investigation into the combined effects of food availability and population density on growth should provide insights into why patterns of variable size-at-age are exhibited among ghost shrimp in Pacific Northwest estuaries. The data presented here provide compelling evidence that biochemical aging techniques can be used to assess age in $N$. californiensis, and LF-based aging should provide researchers with a useful tool to begin exploring some of these factors. The development of a single model to describe age alleviates the inherent problems associated with traditional lengthbased methods of age determination and provides a standard for comparing within and among highly variable ghost shrimp populations in Pacific Northwest estuaries. These methods can be applied to provide a basic understanding of the population biology of the species and other thalassinidean crustaceans and to advance programs aimed to control burrowing shrimp in shellfish aquaculture.

Acknowledgements. This work was funded by USDA-ARS (CRIS Project Number 5358-63000-002-00D) and the Mamie Markham Research Scholarship. We thank A. D'Andrea, V. Gertseva, C. J. Langdon and G. Waldbusser for providing comments and assisting in manuscript preparation. S.-J. Ju and L. McCoy provided technical assistance in laboratory and field work. Thanks to C. Fritz and R. Hildebrand for help with data collection and sample preparation.

\section{LITERATURE CITED}

> Abed-Navandi D, Dworschak PC (2005) Food sources of tropical thalassinid shrimps: a stable isotope study. Mar Ecol Prog Ser 291:159-168

> Belchier M, Edsman L, Sheehy MRJ, Shelton PMJ (1998) Estimating age and growth in long-lived temperate freshwater crayfish using lipofuscin. Freshw Biol 39:439-446

> Bhattacharya CG (1967) A simple method of resolution of a distribution into Gaussian components. Biometrics 23: 115-135

Bird EM (1982) Population dynamics of thalassinidean shrimps and community effects through sediment modification. PhD dissertation, University of Maryland, College Park, MD

Bluhm BA, Brey T (2001) Age determination in the Antarctic shrimp Notocrangon antarcticus (Crustacea: Decapoda), using the autofluorescent pigment lipofuscin. Mar Biol 138:247-257

> Bluhm B, Brey T, Klages M, Arntz WE (2001a) Occurrence of the autofluorescent pigment, lipofuscin, in polar crus- 
taceans and its potential as an age marker. Polar Biol 24: 642-649

Bluhm BA, Brey T, Klages M (2001b) The autofluorescent age pigment lipofuscin: key to age, growth and productivity of the Antarctic amphipod Waldeckia obesa (Chevreux, 1905). J Exp Mar Biol Ecol 258:215-235

Boon PI, Bird FL, Bunn SE (1997) Diet of the callianassid shrimps Biffarus arenosus and Trypaea australiensis (Decapoda: Thalassinidea) in Western Port (southern Australia), determined with multiple stable isotope analyses. Mar Freshw Res 48:503-511

Cassidy K (2008) Use of extractable lipofuscin as an age biomarker to determine age structure of ghost shrimp (Neotrypaea californiensis) populations in west coast estuaries. MS thesis, Oregon State University, Corvallis, OR

> D'Abramo LR, Heinen JM, Robinette HR, Collins JS (1989) Production of the freshwater prawn Macrobrachium rosenbergii stocked as juveniles at different densities in temperature zone ponds. J World Aquacult Soc 20:81-89

D'Andrea AF, DeWitt TH (2009) Geochemical ecosystem engineering by the mud shrimp Upogebia pugettensis (Crustacea: Thalassinidae) in Yaquina Bay, Oregon: density-dependant effects on organic matter remineralization and nutrient cycling. Limnol Oceanogr 54:1911-1932

DeWitt TH, Wellman KF, Wildman T, Armstrong DA, Bennett L (1997) An evaluation of the feasibility of using integrated pest management to control burrowing shrimp in the commercial oyster beds. Report prepared for the Washington Department of Ecology by Batelle, Pacific Northwest Division, Richland,WA

DeWitt TH, D'Andrea AF, Brown CA, Griffen BD, Eldridge PM (2004) Impact of burrowing shrimp populations on nitrogen cycling and water quality in western North American temperature estuaries. In: Tamaki A (ed) Proceedings of the symposium on ecology of large bioturbators in tidal flats and shallow sublittoral sedimentsfrom individual behavior to their role as ecosystem engineers, November 2003. Nagasaki University, Nagasaki, p 107-115

> Dumbauld BR, Armstrong DA, Feldman KL (1996) Life-history of two sympatric thalassinidean shrimps, Neotrypaea californiensis and Upogebia pugettensis, with implications for oyster culture. J Crustac Biol 16:689-708

> Dumbauld BR, Brooks KM, Posey MH (2001) Response of an estuarine benthic community to application of the pesticide carbaryl and cultivation of Pacific oysters (Crassostrea gigas) in Willapa Bay, Washington. Mar Pollut Bull 42:826-844

> Dumbauld BR, Booth S, Cheney D, Suhrbier A, Beltran H (2006) An integrated pest management program for burrowing shrimp control in oyster aquaculture. Aquaculture 261:976-992

> Dumbauld BR, Ruesink JL, Rumrill SS (2009) The ecological role of bivalve shellfish aquaculture in the estuarine environment: a review with application to oyster and clam culture in West Coast (USA) estuaries. Aquaculture 290: 196-223

Ettershank G, Macdonnell I, Croft R (1983) The accumulation of age pigment by the fleshfly Sarcophaga bullata Parker (Diptera: Sarcophagidae). Aust J Zool 31:131-138

Feldman KL, Armstrong DA, Dumbauld BR, Dewitt TH, Doty DC (2000) Oysters, crabs, and burrowing shrimp: review of an environmental conflict over aquatic resources and pesticide use in Washington State's (USA) coastal estuaries. Estuaries 23:141-176

Gayanilo FC Jr, Sparre P, Pauly P (2005) FAO/ICLARM stock assessment tools (FiSAT II). FAO, Rome
Griffis RB, Suchanek TH (1991) A model of burrow architecture and trophic modes on thalassinidean shrimps (Decapoda: Thalassinidea). Mar Ecol Prog Ser 79:171-183

Gu H, Anderson AJ, Mather PB, Capra MF (1996) Effects of feeding level and starvation on growth and water and protein content in juvenile redclaw crayfish, Cherax quadricarinatus (von Martens). Mar Freshw Res 47:745-748

Gulland JA, Rosenberg AA (1992) A review of length-based approaches to assessing fish stocks. FAO Fisheries Technical Paper 323, FAO, Rome

Hartnoll RG (1982) Growth. In: Bliss DE, Abele LG (eds) The biology of Crustacea. 2. Embryology, morphology and genetics. Academic Press, New York, NY, p 111-196

> Hartnoll RG (2001) Growth in Crustacea-twenty years on. Hydrobiologia 449:111-122

> Harvey HR, Secor DH, Ju SJ (2008) The use of extractable lipofuscin for age determination of crustaceans: reply to Sheehy (2008). Mar Ecol Prog Ser 353:307-311

Hasselblad V (1966) Estimation of parameters for a mixture of normal distributions. Technometrics 8:431-444

Hedgepeth J, Obrebski S (1981) Willapa Bay: a historical perspective and a rationale for research. FWS/OBS-81/03, Office of Biological Services, US Fish and Wildlife Service, Washington, DC

Hickey BM (1989) Patterns and processes of circulation over the shelf and slope. In: Hickey BM, Landry MR (eds) Coastal oceanography of Washington and Oregon. Elsevier, Amsterdam, p 41-115

Hilborn R, Walters CJ (1992) Quantitative fisheries stock assessment: choice, dynamics and uncertainty. Chapman and Hall, London

Ingle L, Wood TR, Banta AM (1937) A study of the longevity, growth, reproduction and heart rate in Daphnia longispina as influenced by limitations on quantity of food. J Exp Zool 76:325-352

> Ju SJ, Secor DH, Harvey HR (1999) Use of extractable lipofuscin for age determination of the blue crab, Callinectes sapidus. Mar Ecol Prog Ser 185:171-179

> Ju SJ, Secor DH, Harvey HR (2001) Growth rate variability and lipofuscin accumulation in the blue crab Callinectes sapidus. Mar Ecol Prog Ser 224:197-205

Ju SJ, Secor DH, Harvey HR (2002) Demographic assessment of the blue crab (Callinectes sapidus) in Chesapeake Bay using extractable lipofuscins as age markers. Fish Bull 101:312-320

Klein Breteler WC (1975) Laboratory experiments on the influence of environmental factors on the frequency of moulting and the increase in size at moulting of juvenile shore crabs, Carcinus maenas. Neth J Sea Res 9:100-120

Kodama K, Shiraishi H, Morita M, Horiguchi T (2006) Verification of lipofuscin-based crustacean ageing: seasonality of lipofuscin accumulation in the stomatopods Oratosquilla oratoria in relation to water temperature. Mar Biol 150:131-140

Lutz CG, Wolters WR (1986) The effect of five stocking densities on growth and yield of red swamp crayfish Procambarus clarkia. J World Aquacult Soc 17:33-36

MacGinitie GE (1934) The natural history of Callianassa californiensis Dana. Am Midl Nat 15:166-177

MacGinitie GE (1935) Ecological aspects of a California marine estuary. Am Midl Nat 16:709-712

Manning RB, Felder DL (1991) Revision of the American Callianassidae (Crustacea: Decapoda: Thalassinidea). Proc Biol Soc Wash 104:764-792

> Mason DT (1963) The growth response of Artemia salina (L.) to various feeding regimes. Crustaceana 5:138-150

Maxwell KE, Matthews TR, Sheehy MRJ, Bertelsen RD, 
Derby CD (2007) Neurolipofuscin is a measure of age in Panulirus argus, the Caribbean spiny lobster, in Florida. Biol Bull 213:55-66

Naranjo-Páramo J, Hernandez-Llamas A, Villarreal H (2004) Effect of stocking density on growth, survival and yield of juvenile redclaw crayfish Cherax quadricarinatus (Decapoda: Parastacidae) in gravel-lined commercial nursery ponds. Aquaculture 242:197-206

Newell RC (1969) Effect of fluctuations in temperature on the metabolism of intertidal invertebrates. Am Zool 9:293-307

Newman GG, Pollock DE (1974) Growth of the rock lobster Jasus lalandii and its relationship to benthos. Mar Biol 24: 339-346

O'Donovan V, Tully O (1996) Lipofuscin (age pigment) as an index of crustacean age: correlation with age, temperature and body size in cultured juvenile Homarus gammarus L. J Exp Mar Biol Ecol 207:1-14

Parsons DG, Fréchette J (1989) Fisheries for northern shrimp (Pandalus borealis) in the Northwest Atlantic from Greenland to the Gulf of Maine. In: Caddy JF (ed) Marine invertebrate fisheries: assessment and management. WileyInterscience, London, p 63-86

Percy KL, Bella DA, Sutterlin C, Klingeman PC (1974) Descriptions and information sources for Oregon estuaries. Oregon Sea Grant Program, Oregon State University, Corvallis, OR

Posey MH (1986) Changes in a benthic community associated with dense beds of a burrowing deposit feeder, Callianassa californiensis. Mar Ecol Prog Ser 31:15-22

Posey MH (1987) Effects of lowered salinity on activity of the ghost shrimp Callianassa californiensis. Northwest Sci 61: 93-96

Porta EA (1991) Advances in age pigment research. Arch Gerontol Geriatr 12:303-320

Puckett BJ, Secor DH, Ju SJ (2008) Validation and application of lipofuscin-based age determination for Chesapeake Bay blue crabs Callinectes sapidus. Trans Am Fish Soc 137:1637-1639

R Development Core Team (2008) R: a language and environment to statistical computing, reference index, Version 2.8.1. R Foundation for Statistical Computing, Vienna, Austria. Available at: www.R-project.org

Ra'anan Z, Cohen D (1985) Ontogeny of social structure and population dynamic in the giant freshwater prawn, Macrobrachium rosenbergii (de Man). In: Wenner AM (ed) Crustacean issues. 3. Factors in adult growth. AA Balkma, Rotterdam, p 277-311

Ruesink JL, Feist BE, Harvey CJ, Hong JS, Trimble AC, Wisehart LC (2006) Changes in productivity associated with four introduced species: ecosystem transformation of a 'pristine' estuary. Mar Ecol Prog Ser 311:203-215

Sheldahl JA, Tappel AL (1974) Fluorescent products from aging Drosophila melanogaster: an indicator of free radical lipid peroxidation damage. Exp Gerontol 9:33-41

Sheehy MRJ (1989) Crustacean brain lipofuscin: an examination of the morphological pigment in the fresh-water crayfish Cherax cuspidatus (Parastacidae). J Crustac Biol 9: 387-391

Sheehy MRJ (1990a) Widespread occurrence of fluorescent morphological lipofuscin in the crustacean brain. J Crustac Biol 10:613-622

Sheehy MRJ (1990b) Potential of morphological lipofuscin

Editorial responsibility: Romuald Lipcius,

Gloucester Point, Virginia, USA age-pigment as an index of crustacean age. Mar Biol 107: 439-442

Sheehy MRJ (1996) Quantitative comparison of in situ lipofuscin concentration with soluble autofluorescence intensity in the crustacean brain. Exp Gerontol 31:421-432

Sheehy MRJ (2008) Questioning the use of biochemical extraction to measure lipofuscin for age determination of crabs: comment on Ju et al. (1999, 2001). Mar Ecol Prog Ser 353:303-306

Sheehy MRJ, Greenwood JG, Fielder DR (1994) More accurate chronological age determination of crustaceans from field situations using the physiological age marker, lipofuscin. Mar Biol 121:237-254

Sheehy MRJ, Greenwood JG, Fielder DR (1995) Lipofuscin as a record of rate of living in an aquatic poikilotherm. J Gerontol 50A:327-336

Sheehy MRJ, Shelton PMJ, Wickins JF, Belchier M, Gaten E (1996) Ageing the European lobster Homarus gammarus by the lipofuscin in its eyestalk ganglia. Mar Ecol Prog Ser 143:99-111

Sheehy MRJ, Caputi N, Chubb C, Belchier M (1998) Use of lipofuscin for resolving cohorts of western rock lobster (Panulirus cygnus). Can J Fish Aquat Sci 55:925-936

Sheehy MRJ, Bannister RCA (2002) Year-class detection reveals climatic modulation of settlement strength in the European lobster, Homarus gammarus. Can J Fish Aquat Sci 59:1132-1143

Sheehy MRJ, Prior AE (2005) Analysis of stock age structure and population parameters in edible crab, Cancer pagurus, using lipofuscin age pigments: data for resource management. Marine Fisheries R and D, Final Report MF0225, Department for Environment, Food and Rural Affairs, London

Sheehy MRJ, Prior AE (2008) Progress on an old question for stock assessment of edible crab Cancer pagurus. Mar Ecol Prog Ser 353:191-202

Shirzad FF, Orlando SP, Klein CJ, Holliday SE, Warren MA, Monaco ME (1988) National estuary inventory, Suppl 1. Physical and hydrologic characteristics. The Oregon estuaries. Rockville, MD. US Department of Commerce, National Oceanic and Atmospheric Administration

Smith PK, Krohn RI, Hermanson GT, Mallia AK and others (1985) Measurement or protein using bicinchoninic acid. Anal Biochem 150:76-85

Sohal RS (1981) Relationship between metabolic rate, lipofuscin accumulation, and lysosomal enzyme activity during aging in the adult housefly, Musca domestica. Exp Gerontol 16:347-355

Sokal RR, Rohlf FJ (1995) Biometry: the principles and practice of statistics in biological research, 3rd edn. WH Freeman, New York, NY

Vila Y, Medina A, Megina C, Ramos F, Sobrino I (2000) Quantification of the age pigments lipofuscin in brains of known-age, pond-reared prawns Penaeus japonicus (Crustacea, Decapoda). J Exp Zool 286:120-130

Wahle RA, Tully O, O'Donovan V (1996) Lipofuscin as an indicator of age in crustaceans: analysis of the pigment in the American lobster Homarus americanus. Mar Ecol Prog Ser 138:117-123

Washington Department of Fisheries (1970) Ghost shrimp control experiments 1960-1968. Washington Department of Fisheries Technical Report 1, Olympia, WA

Submitted: October 8, 2009; Accepted: January 26, 2011

Proofs received from author(s): April 8, 2011 